Hürol, Y., (2009) “Can Architecture be Barbaric?” Science and Engineering Ethics. 15(2). pp.233-258.

This is the last version of the article after the refereeing process and just before the publication.

\title{
CAN ARCHITECTURE BE BARBARIC?
}

\section{Yonca Hurol}

\section{INTRODUCTION}

On $17^{\text {th }}$ of August 1999 the Kocaeli earthquake, which had a magnitude of 7.4, killed over 40.000 people, including the missing people, and destroyed over 300.000 homes. [1] After this earthquake the Turkish Chamber of Architects and Engineers criticized the building market / sector, the existing political economy, and the lack of people's rights in Turkey, because the agreement between the people and the state was broken by the state by not providing the promised protection for people. [2] The faculty council of the Middle East Technical University (METU), the Faculty of Architecture, dedicated the following academic year to learning and teaching about earthquakes. [3] However, nobody has made any 'architectural interpretations about the reasons and consequences of this earthquake, and its subsequent influence on the future of architecture in Turkey, but the dean of the Faculty of Architecture at METU, Necdet Teymur, ${ }^{1}$ wrote some 'earthquake poems' and published them as a book. [7]

\footnotetext{
${ }^{1} \mathrm{~N}$. Teymur is known as a rational and analytical academic of architecture. He has written books and articles about architectural education and architectural theory.

According to Teymur, the knowledge of architecture is complex and layered. He postulates that economy has a determining effect on both the ideology of architecture and architectural education. Thus, both the ideology and the knowledge of the profession are determined by the sovereign groups within society. The beliefs and philosophies of these groups, in turn, consequently, created confusion and conflict within the architectural profession, which resulted in a considerable lack of knowledge about the architectural profession itself. Teymur, therefore, suggested that the Institution of the Chamber of Architects should organize a systematic and analytical research into the field of architecture. [4] This was before the 1999 earthquake.
}

Although Teymur is analytical about specific subjects, his books, which are about architecture in general, have a different character. In his books "Re-Architecture" [6] and "Learning from Disasters" [3] he brings different examples, thoughts, photographs etc. side by side in order to reveal some political truths about architecture. This book also has a poetic nature, in which Teymur is indirect, and he makes his readers think about and reflect on each issue. It is possible to say that, if there is sufficient knowledge about a subject, Teymur works on it analytically and rationally. However, if there is insufficient knowledge and information, he encourages people to think about this subject from an artistic perspective by writing poems.

The architectural profession lacks knowledge and information generally and especially in respect of the subject of earthquakes. Thus, Teymur treats this subject poetically (therefore indirectly) whilst supporting the politics of the Turkish Chamber of Architects. He wished people to understand and answer this question. This article, therefore, offers the results of this research in a question form, and also supplies an answer to it. 
In one of these somewhat rational poems there is a section, which was written in reference to Theodor Wiesengrund Adorno, who was a member of the Frankfurt School, and one of the founders of Critical Theory. This important section, which might give rise to healthy architectural interpretations about the Kocaeli earthquake, is as follows:

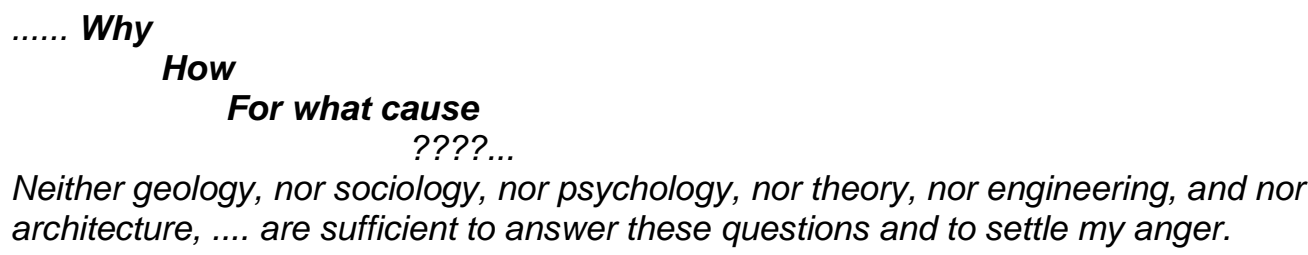

Building activity can never cease. Thus, Teymur meant something else by questioning the possibility of architecture since he defends that all building activity should be accepted as architecture. [5] Therefore, his question can only refer to the ethics of architecture.

Adorno`s original statement, which corresponds to Teymur's question is: '...To write poetry after Auschwitz is barbaric....' This statement appeared in an article called: “Cultural Criticism and Society," which was written in 1949 after the liberation of the evacuated Auschwitz by Soviet troops at the beginning of 1945, and printed in the book called 'Prisms' in 1967. [8, 9, pp.17-34] Adorno, continued to defend the same perspective after reading Paul Celan's (Antschel) important poem: "Death Fugue” (Todesfuge), although he always insisted on: 'the need to let suffering speak.' 'Death Fugue' which is about Auschwitz, was published in the 1950's, and is in German. $[10]$

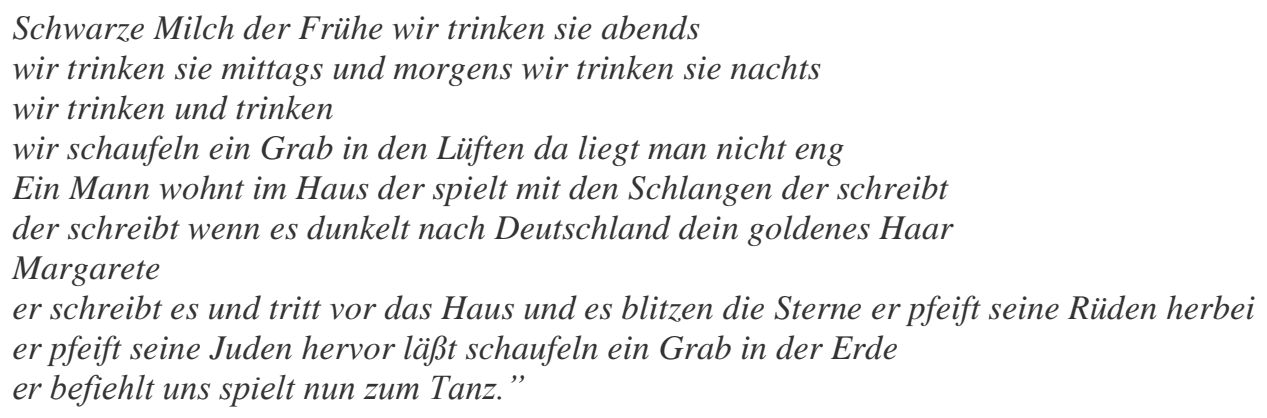

Black milk of daybreak we drink it at nightfall / we drink it at midday and morning we drink it at night /drink it and drink it / we shovel a grave in the air there you won't lie too cramped / A man in the house he plays with the serpents he writes / he writes when it grows dark to Deutschland your golden hair /Margarete / he writes it and walks from the house the stars glitter he whistles his dogs up / he whistles his Jews out and orders a grave to be dug in the ground / he orders us strike up and play for the dance. / [11]

Referring to this poem Adorno said: 'This is too beautiful. One cannot write beautiful poems about the Holocaust. One can only be silent in the face of what happened there. No lyrical poetry after Auschwitz!' [12] It 
seems that Adorno felt doubtful as to whether the concept of poetry as a whole was generally culpable or only lyrical poetry. Since the original dictum blames poetry in general, and since Teymur refers to that dictum, I will focus on the original dictum within this text.

On the other hand, Celan, who witnessed the death of his family in Auschwitz, became silent in the 1960's; and he stopped publishing and reading his poetry in front of audiences. [13] Even in his -unfinished- last book ‘Aesthetic Theory’ Adorno did not change his mind about Celan`s poetry. [14, pp.321-2]

However, Adorno's dictum should not be understood as a declaration of the end of poetry after Auschwitz. He never stopped producing his "atonal philosophy" [15, pp.56-81] about the role and importance of poetry (and especially lyrical poetry) for society. Poetry was crucial for all the Frankfurt School philosophers. Adorno`s friend, W. Benjamin developed a major part of his philosophy by interpreting the poetry of C. Baudelaire. Similarly, Adorno wished to dedicate his last book "Aesthetic Theory" to S. Beckett, because of his poetic theatre plays. [14, p.366] He worked on the poetry of many poets, such as Stephan George and Hugo von Hofmannsthal. [9, pp.189-226] In order to discuss the importance of poetry he worked on Mörike's and Eichendorff's poetry in his 'Notes to Literature.' Thus, understanding the extent of the generality / particularity of Adorno's dictum requires careful interpretation and in-depth thinking. Is it applicable only to poetry? It starts being applicable in respect of Auschwitz, but until when? The answers to these questions requires penetration into the various levels of Adorno`s philosophy, such as the politico-economic, the socio-psychological, and the cultural.

The three interrelated objectives of this article are:

1. To understand and interpret Teymur's question about architecture and architectural technology in the light of Adorno's philosophy, and to show that this question points out an ethical problem of architectural aesthetics under totalitarian conditions.

2. To suggest to architects that they can consider avoiding this ethical problem behind aesthetics of architecture. These first two research objectives solely concerned with the issue of how architects and sometimes structural engineers should conduct their business. They are not related to the activities of contractors.

3. To understand the level of generality / particularity of Adorno's dictum, with the help of Teymur's question.

Thus, the point of view and the main concepts of this research are based on Adorno's philosophy.

According to D. Cunningham and N. Mapp [16, p.4]: 'If Adorno is coming into favour today, then, it is surely in part because of his insistence on the possibility of making value judgments....' R. Kaufman's [17] research about Adorno's dictum's generality / particularity through understanding poetic responses and the feelings of the Auschwitz victims, is similar to looking directly into a very bright source of light, which creates a blinding glare. Similarly, other research into Adorno's dictum, such as that carried out by S. Gubar [18] and K. Hofmann [19], are based on the negative feelings of the contemporary poets rather than a better understanding of the conditions 
of the dictum. For example, Gubar [18, p.263] sees Auschwitz and Adorno's dictum as two important obstacles that modern poetry has managed to survive and overcome. H. Caygill [20, p.83] analyzes the conditions of possibility of poetry prior to Auschwitz on the basis of Adorno's 'Notes to Literature,' and concludes that lyric poetry 'cannot continue to exist within its previous conditions of possibility.' On the other hand, Zilcosky [21] thinks that Adorno's dictum is a challenge for poetry (not a verdict), which effected all poets including Celan positively.

Teymur's poem about the earthquake disaster in Turkey provides the required indirect aspect and shows once more that recalling and referring to Adorno's truth is still highly relevant.

The results of this research may prove useful in respect of contemplating the issue of the ethics of aesthetics in architecture, and structural engineers' contributions to the aesthetics of architecture. The results can be directly applied to the issue of architecture within disaster zones, war, civil-war zones, and to that of architecture in respect of homeless people. It can also provide a basis for contemplating the ethics of architecture in respect of all types of totalitarian conditions. For example, Tibet's claim about Herzog \& de Meuron's design for the Olympic Stadium in Beijing, which has a design concept of bird's nest, can be better understood with the support of this research. On the other hand, the research also provides a philosophical contribution by clarifying the generality of Adorno's dictum.

This article focuses on the two types of art (and especially poetry), which were described by Adorno. One of these is: 'authentic art, ' which is a product of a dialectical conflict between the individual artist and society, and the other is art, which is not based on any conflict as such. This last type of art may be designed as a profitable product of the: 'culture industry,' or it may be produced in memory of wars, and genocides, as in the poetry of Celan. [14, pp.321-2, p.311] After examining art as a product of social conflict and art, which is not based on any conflict, the article goes on to produce a discussion, which connects the conceptual thinking in respect of the field of poetry to that of architecture. Thus, the questions, which lead to the research objectives of this article, proceed as follows:

1. What is authentic poetry / art, which is based on social conflict?

2. What is authentic architecture?

3. What is barbaric poetry / art, which is not based on social conflict?

4. What is barbaric architecture?

5. What can be suggested to architects so that they do not produce barbaric architecture?

Consequently, the paper's conclusion offers an interpretation of Teymur's question and Adorno`s dictum using the reciprocal reflection between them as an aid to this, and it also suggests an ethical aesthetic, which could support work of the architects involved within disaster / war zones and totalitarian conditions.

\section{WITHIN THE CONFLICT}

\section{Background}

Understanding Adorno's dictum requires the understanding of Adorno's basic concepts of: 
- 'Negative dialectics,' is a reflection between antagonistic concepts, which are 'pure' and opposite concepts. [22, p.141] Adorno's reflections on the issue of antagonistic concepts of subjectivity / objectivity, and the manner in which he develops the concept of "subjective objectivity" is a good demonstration of the application of negative dialectics. According to this approach, there cannot be any 'pure' objectivity or subjectivity. Each more or less they includes the other. Everyone has a different view of the concept of objectivity, and therefore, because of these differences everyone has their own personal approach to the issue. Different to dialectics, negative dialectics does not accept that there is anything pure on this world. It only helps us to understand these mixed or hybrid things in terms of a struggle between opposite couples of pure concepts. [23] The individual, who is autonomous within society, experiences 'an object' and feels attracted by its ethical gravity. This can also be understood as a particular type of 'becoming' of the subject, who senses and thinks of 'the object' simultaneously. Thus, a reciprocal reflection occurs between the antagonistic concepts about the `category` (or identity) of 'the object.'

"The only way out of the dialectical context of immanence is by that context itself... Dialectics is critical reflection upon that context. It reflects its own motion. .....” [22, p.141]

- 'barter society,' - corresponds to any group of people whose value system is based on mechanistic materialism, [22, pp.135-207, p.146]

- 'culture industry,' - represents the continuous reproduction of cultural objects on the basis of their exchange value,

- 'artistic fetishism,' - signifies the end of 'objectivity' in art. The exchange value of commodities is determined according to their rank within the marketplace. The 'fetish' character of this type of artwork depends on this ranking system, which is the artwork's only use-value. A product of the culture industry is also viewed as a fetish from the perspective of the artist as the creative subject, because it is the object, which has the ultimate priority during the design process, which, consequently, reflects the identity of the artist. [24, pp.120-167, 25, pp.53-113]

- 'identity thinking,' - implies the selection of one of the antagonistic approaches such as 'pure' objectivity and 'pure' subjectivity in architecture. [22, pp.135-207]

- ' 'authentic art,' - is the art which is critical of society, [14, p.311]

- 'an individual,' - e.g. an individual artist is somebody, who can provide an autonomous critique ('import' in Adorno's terminology) which will provide a contribution ('function') to his/her society, through his/her art, [14, p.4]

- 'barbarism,' is a state in which the whole mass of the population and authorities favour and impose, what is named, 'identity thinking,' $[9, \mathrm{p} .34]$

- ' 'poetry,' - is the strongest tool for representing peaceful attitudes against social antagonisms,

- 'nature' - is the main source of bodily experience. Thus, it enables contemporary people to recognize and become aware of the connection between their minds and their bodies. [26]

Since these concepts form the very basic and well covered ground in Adorno's philosophy, this paper does not offer any further discussions on them. 
The main statement of this paper is that Adorno's dictum is valid in certain barbaric social conditions, which result in the disappearance of the critical individual.

Since there are differences between the 'identity thinking' and the way 'individuals' (including artists and architects) think, a dialectical conflict occurs between the people of the consumer society and these 'autonomous' individuals. The individual and the artist can be responsible for his/her society only if s/he is autonomous and independent from the power relationships and ideologies created by society. [14, p.4, p.125] Societies emerge as a result of the influential existence of autonomous individuals, who offer objective critiques of their society and culture, and, thus, both prepare and encourage the people and the political authorities to and for change. According to Adorno's 'critical insight' [27, p.15] 'the essential nature of society' is the existence of the 'contradiction, the potential, the possibilities for changing society's whole constitution.' Most of the individuals disappear if the mass (not society) accepts one of the extreme thoughts, which previously formed the 'legs' of 'negative dialectics.' Adorno defines 'barbarism' as the acceptance and application of one of the extremes by the authorities and the majority of the population.

.....The more total society becomes the greater the reification of the mind and the more paradoxial its effort to escape reification on its own. Even the most extreme consciousness of doom threatens to degenarete into idle character. Cultural criticism finds itself faced with the final stage of the dialectic of culture and barbarism. To write poetry after Auschwitz is barbaric. ${ }^{2}$ And this corrodes even the knowledge of why it has become impossible to write poetry today. Absolute reification, which presupposed intellectual progress as one of its elements, is now preparing to absorb the mind entirely. Critical intelligence cannot be equal to this challenge as long as it confines itself to self-satisfied contemplation. [9, p.34]

Adorno offers an individualistic foundation for all possible social resistance against the 'culture industry,' which depends on the diminishment of traditional forms of resistance and obedience within cultures. [25, p.92]

On the other hand, understanding Teymur's question also requires an understanding of the determining effect of an architect also being an individual, on his/her creativity in respect of building and building technology.

\section{The Individual}

According to Adorno, although the concepts of society and the individual seem to be antagonistic, there is a reciprocal reflection (negative dialectics) between them. Adorno`s concept of the individual, which depends on such a reciprocal reflection between society and the individual, can be better understood if it is compared with $\mathrm{H}$. Arendt`s and E. Levinas`s corresponding concepts. Although Adorno, Arendt, and Levinas both had Jewish connections, each of them defended a different type of relationship between society and the individual. However, the starting point for all of them is Auschwitz.

Arendt's 'personal' ethics $[28,29,30]$ depends on a one sided reflection of the person's effect on society.

\footnotetext{
${ }^{2}$ I wrote this statement in bold.
} 
... 'Persona,' at any event, originally referred to the actor's mask that covered his individual 'personal' face and indicated to the spectator the role and the part of the actor in the play. But in this mask, which was designed and determined by the play, there existed a broad opening at the place of the mouth through which the individual, undisguised voice of the actor could sound. It is from this sounding through that the word 'persona' was derived: 'per-sonare,' 'to sound through,' is the verb of which 'persona,' the mask, is the noun.... [30, pp.12-13]

Arendt's 'persona' differs from Adorno's individual, because the word 'persona' does not reflect society per se. Persona implies a 'him/herself' as an authentic entity to reflect on others. Persona affects the society, but does not get affected by it. The actions of society cannot reach the back of the person's 'mask.' According to Arendt, the 'persona' is morally and politically needed in order to be able to talk through any required mask, such as the mask of the professional in respect of presentation, regardless of possible underlying personal feelings or judgements. However, this aspect differs considerably from that of Adorno's demand of 'non-identity' for the individual.

....the concept of the person as well as its variants - the 'I-thou' relation, for example - have assumed the oily tone of un-believed theology. We cannot anticipate the concept of the right human being, but it would be nothing like the person, that consecrated duplicate of its own selfpreservation. From the viewpoint of a philosophy of history, this concept, which on the one hand assuredly presupposes a subject objectified into a character, presupposes on the other hand the subject's disintegration. Complete weakness of the ego, the subject's transition to a passive, atomistic, reflex-type conduct, is at the same time the well-earned judgment passed upon a "person" in which the economic principle of appropriation has become anthropological. [22, p.277]

Totality is to be opposed by convicting it of nonidentity with itself - of the nonidentity it denies, according to its own concept. Negative dialectics is thus tied to the supreme categories of identitarian philosophy as its point of departure... [22, p.147]

Thus, the 'pure' subjectivity in architecture, which is not possible according to Adorno, has parallels with Arendt's concept of 'persona.'

The concept of 'non-identity' is negatively related to the concept of unity, in other words, the division of the concept of self into fragments. According to Adorno [22, p.317], the concept of unity is, in itself, antagonistic. '... Unity is division....'

Levinas describes a second one-sided reflection between the person and the society. Levinas's society reflects itself on each person through the 'love' in the 'face' of each neighbour. The neighbour's face (not the enemy's) invites people to reciprocal love. This "face" is sacred, and seen as a good personal reason against all enmities 
and massacres between neighbours. [31, p.194, 32, pp.121-125] The responsibility of each person, ${ }^{3}$ then, is his/her ability to respond to the others (neighbours) with love. [33, 34, pp.63-76] Here, people determine each other, and the majority determines the minority. This is an ideal community, which is in perfect unity. Priority is given to the love between neighbours, rather than the autonomy of individuals, including artists and architects.

On the other hand, Adorno's concepts of the individual and society have a reciprocal reflection existing between the two. This is not a one-sided reflection of either the person or the society over the other. Adorno's individual concept expresses the -scars of- society more than Arendt's subjective "persona," and it is of a more autonomous nature than that of Levinas's person, who needs to be loved by his/her neighbours. Arendt's "persona" can easily be deformed to become artistic fetishism. Similarly, Levinas`s community, which is in unity, because of people's obedience to the religious / cultural values [34, p.69], can easily be deformed and used for the political purposes of the corrupt authorities. Corrupt authorities usually impose the ideology of nationalistic or religious unity and the pragmatist barter principle simultaneously in order to achieve better control of the population. [1] According to Adorno`s philosophy, Arendt`s and Levinas`s concepts can be accepted as complementary concepts, which may co-operate to form the antagonistic forces within the culture industry.

\section{Technology in Art}

The relationship between technology and art differs radically depending on the art's relationship with the market; in other words, with the 'culture industry.' If artwork is a product of the culture industry, then it is determined by 'a false rationality of an industry oriented to profit.' [14, p.206] This part of this paper contains information only about the relationship between technology and 'authentic' artwork, and not the products of the culture industry.

'Authentic' artwork is not designed to be a commodity, which is geared towards profit. However, it can still be sold. Adorno's concept of authentic artwork can be understood in terms of the relationship between its form and its material, as well as the autonomous spirit of the artist, and including his/her objectivity and subjectivity. According to Adorno, [14, pp.127-145] the spirit of the artist is reflected in the form of the authentic artwork. However, this is not a playful approach to form. It is rather a materialistic approach, according to which form is related to its material. This material in the case of poetry, e.g. is language. Similarly, we are unable to imagine a structurally weak and badly detailed authentic architecture. Thus, technology, which is strongly related to the concepts of form and material, is not an art tool. It is a part of design and it is the reason for authentic art. It does not only solve technical problems as it was designed to do in most of the Functionalist architecture of the early $20^{\text {th }}$ century, but it also has ornamental characteristics. Adorno suggests that architects combine the concepts of 'functional detail' and 'ornamental detail.' [35] Thus, according to Adorno, art is 'rational.' [14, pp.303-7] His approach to dialectics in art, therefore, makes him a technisist as such.

Adorno's concept of 'artistic rationality' is different from that of the concept of "instrumental rationality," which encourages "identity thinking." An authentic art object's form is created by the intellect of the thinking

\footnotetext{
${ }^{3}$ Again according to Levinas, [33, 34] the only way of leaving a responsibility to the others is being responsible from the responsibility of these others.
} 
spirit. It reflects both the feelings and the mind of the artist. '...In artworks, form is aesthetic essentially insofar as it is an objective determination. Its locus is precisely there where the work frees itself from being simply a product of subjectivity...' [14, p.142]

What Adorno means by 'form,' differs from the 'schematic,' not only by relating the form to the materials. '...Yet artworks distinguish themselves productively from the merely schematic exclusively by the element of the autonomy of their details...' The details of artworks (Adorno gives examples from classical music) behave just as the autonomous individuals do within the society. They gain their autonomy, which does not necessarily mean being irresponsible towards the whole. [14, pp.303-4] They can be seen as ironic or witty parts of the whole. Thus they are not obedient to the whole. For example, Mies van der Rohe's main design idea is to express the steel frame structures in his architecture. However, all the steel members used are covered with protective layers, which create the visual illusion that there is no covering. Mies thinks that the frames with specially covered steel members can even represent steel frames better than those without a covering. Similarly, passages of classical music contain such individual details between them. The technique of relating poetical texts to each other, without damaging the grammar, also appears as individuals appear within society.

Thus, we can start imagining another form of architecture, in which the technical details are not separate from the architectural design. Although buildings are seen as masses when looked at from a distance, construction details on their surfaces might appear like `assemblages` when people move closer to them, or as `fragments, when people are distant. ${ }^{4}$ [36, pp.215-26] The reconciliation between the autonomous details and the 'whole,' is possible only if there is reconciliation between the autonomous artist and society. An artist needs the experience of being an individual in order to be able to design such details, which show themselves within the whole design as individuals show themselves within society. Otherwise, s/he cannot own the feelings attached to the concept of being an individual.

\section{Replacing Poetry with Architecture}

The technology of architecture is very different from the technology of poetry. This needs careful consideration whilst interpreting Teymur`s replacement of poetry with architecture in his question ('Is architecture possible after 17th of August?'), which is a reflection of Adorno's dictum ('To write poetry after Auschwitz is barbaric. ').

H. Heynen, an architect who related Adorno's philosophy to architecture, presents opposing thoughts to those of Teymur in her writings. She [38] says that according to Adorno's philosophy, there are two main differences between architecture and the other art types, such as poetry. The first is the acceptance of the capitalistic division of labour, which devalues physical labour by excluding it from the design and decision giving activities, within

\footnotetext{
${ }^{4}$ The concept 'assemblage' is a part of G. Deleuze and F. Guattari's terminology. Thay say that: [37, p.88]

"We may draw some general conclusions on the nature of Assemblages... On a first, horizontal, axis, an assemblage comprises two segments, one of content, the other of expression. On the one hand it is a 'machinic assemblage' of bodies, of actions and passions, an intermingling of bodies reacting to one another; on the other hand it is a 'collective assemblage of enunciation,' of acts and statements, of incorporeal transformations attributed to bodies. Then on a vertical axis, the assemblage has both 'territorial sides, 'or reterritorialized sides, which stabilize it, and 'cutting edges of deterritorialization, ' which carry it away...."
} 
the processes of modern architectural production. Heynen thinks that the use of modern materials and techniques requires capitalistic production relationships, which are created through the use of 'pure' physical labour (as an extreme) either in factories or on construction-sites, and this may position architecture in 'barbaric' (extreme) situations because of the ignorance of the reduction of labourers into tools of production. Heynen's meaning, indirectly, is that, according to Adorno`s philosophy, this makes the architectural contribution to creativity in the area of building technology inapplicable, because of the impossibility of avoiding its inherent barbarism. However, this is not true and Adorno's [35] only text about architecture: 'Functionalism Today;' is mainly about the 'negative dialectics' between the functional use of technology and functionless character of architectural ornament. He states that both of these two extreme attitudes have fetishist characteristics, because of their extreme characteristics, which are outcomes of identity thinking. He suggests them to be used together in order to highlight the importance of quality of labour, which requires non-mechanistic ways of thinking.

Again according to Heynen, [38] the second distinguishing feature of modern architecture from the other art types is its functionalist approach, which severs its relationship with the daily experiences of people, by transforming the knowledge about 'function / user' into jargon. [38, pp.84-5] Still, Heynen prefers to adopt a critical approach to functionality, but not to technology.

However, according to Adorno, the technological and functional needs of society cannot affect the overall position of architecture as an art.

...no direct relation exists between social need and aesthetic quality, not even in the sphere of socalled functional art... (Here Adorno continued to write about architecture.) ...The quality of artworks can be meaningfully brought into relation with social need only when mediated by a theory of society as a whole, not on the basis of what people need at any given time.... [14, p.315]

The existence of a theory of society in the mind of the artist, who is an autonomous individual, is, according to Adorno, the only need for the production of 'authentic' art. Dixon [39] also says that according to Adorno, technology does not belong only to the area of economy, but it also belongs to the areas of art and theory. Heynen also sees the limiting effects of her interpretation of Adorno, and because of this, she replaces Adorno's concept of the: 'autonomous individual' with the concept of an: 'autonomous moment in design.' By doing this she tries to create some other artistic possibilities for architecture.

...Design is not simply the management of heteronomous principles such as functional or constructive requirements, psychological needs of the consumers, representational demands, and the like. There is always an autonomous moment in the design process in which an architect is occupied with architecture as such... [38, p.85]

This detour in Heynen`s interpretation of Adorno, also serves towards the abandonment of the need for an 'individual's input' in order to produce architecture. Instead, therefore, design, which is a subconscious activity, 
becomes independent and thus subjective. Heynen's abandonment of the principle of individual responsibility is also strongly related to the abandonment of architectural creativity in the area of technology.

There are two considerable differences between Teymur's and Heynen's interpretations of Adorno. The first of these is in respect of Teymur's replacement of poetry with architecture, which highlights the artistic power of architecture and architectural technology. Heynen is rather hesitant about the artistic characteristics of architectural technology, and the issue of the 'autonomy' of the architect as an individual. The second difference is with reference to Heynen's use of the term: 'autonomous moment' only in respect of the critical mimesis (critical approach to a particular type of imitation, which is based on holistic transformation) of functionality, but not with regard to the techniques, materials, and details of architectural technology. This means that according to Heynen, there cannot be critical mimesis in architectural technology, because architectural technology is necessarily conditioned by identity thinking and the issue of barbarism. On the other hand, underlying Teymur's question, when applied in the context of the Kocaeli earthquake, is an implication that the possibility of the artistic use of architectural technology (including structural systems, building materials and details), without limiting any of the architecture's other artistic possibilities, such as critical mimesis of functions, is possible. This is because Teymur believes that there can be a critical mimesis of both architectural technology and functionality within non-barbaric contexts. Also, according to Adorno's philosophy, any individual, objective and rational approach to the art of architecture is possible, but only if dialectical conflicts are also possible within a society.

\section{WITHOUT ANY CONFLICT}

\section{The End of Dialectics}

According to Adorno [22, p.4], the modern way of life severs the relationship between our experiences (feelings) and our minds, as a result of the separation of physical and mental labour, because physical labour is based on experience and thus feelings, whilst mental labour is based on the mental process. This severance consequently causes difficulties in the expression of truth through the use of language, mainly because of the antagonistic nature of concepts, which are the only tools of thought. There remains a few ways to avoid: 'identity thinking.' Since the establishing of the 'purity' of concepts has become more important than establishing the truthful nature of thought in all sciences, the dialectical nature of truth can only be represented by art. According to Adorno, literature, theatre and poetry, amongst other art forms are of special importance, because their intention is to achieve the use of the same antagonistic language within 'truthful' thoughts. These art forms can decrease the 'purity' of concepts by balancing them with the existence of other concepts. One large step forward with a concept, and then two small steps backwards with other balancing concepts...

As a result of the relation and resemblance of life to the lyrical, Adorno also questioned whether any art can be possible after Auschwitz, and whether one can go on living. [40, pp.172-3 in 17, p.104] Any attempt to represent the dialectical nature supports the presence of peaceful thoughts besides the more radical, barbaric thoughts. Inevitably, the 'truth' of art and life seems to be ideological. 
...unreality threatens art permanently with ideology. Art, however, does not sink to the level of ideology, nor is ideology the verdict that would ban each and every artwork from truth. On the basis of their truth, of the reconciliation that empirical reality spurns, art is complicitous with ideology in that it feigns the factual existence of reconciliation.... [14, p.134]

Dialectical conflict is always present between barbaric attitudes and all art forms. However, if barbarism damages society and the dialectical nature of culture by creating incomprehensible extreme situations, as, e.g. as in the case of the Holocaust, then the life sources of literature and poetry might dry up as a result of the disappearance of dialectical conflict between the individual and society. This would mean the reification or disappearance of both the individual and society. According to Adorno, it is: 'not only Auschwitz, but the whole world of torture, which has continued to exist' (he mentions the reports from Vietnam) that has caused change in the 'innermost core' of metaphysics. [40, pp.159-60 in 17, p.95]

It is barbaric to write poetry (or even to live) with such 'broken wings.' According to Adorno, poetry as such:

...yearns neither for nature nor for industry...., and contributes its part to making peace with an unpeaceful world. ... images of the postindustrial world are those of a corpse: they want to avert atomic war by banning it... [14, p.219]

Expression of a dead dialectical conflict is a: 'romantic' attitude, which tends to recreate (remember) the barbaric extreme, which caused the end of the conflict.

\section{Adorno and Celan}

Celan's poetry portrays a `romantic` approach to poetry, which does not reveal the existence of any dialectical conflict between society and the artist. Adorno says that Celan's poems cannot contribute to human culture. Instead, they invite further weaknesses:

...the experiential content of the hermetic was inverted. His (Celan's) poetry is permeated by the shame of art in the face of suffering that escapes both experience and sublimation. Celan's poems want to speak of the most extreme horror through silence. Their truth content itself becomes negative. They imitate a language beneath the helpless language of human beings.... [14, p.322]

According to Zilcosky [21, p.690] the above statements of Adorno show that the 'Adorno /Celan relationship was actually less antagonistic then commonly believed.' Similarly, according to Croggon [10]: '....Celan talks back to the exploded centre of culture in order to transcend this abjected space...' However, this is an impossible transcendence, and Adorno did not support the following view of Croggon in respect of Celan's poetry:

...Celan's work strains the German language through poetry, recasting its innate precision into a state of ambiguity. His multi-faceted project tackles the particular problem of deploying a mother 
tongue degraded by the Third Reich's intensive use of language as a tool of both persuasion and oppression... ...Celan has to be read as a purposeful intervention into an abject language field...

According to Adorno, there can be no cleansing function of the arts (including architecture), since any attempt at achieving such an act is, not only impossible, but also totally barbaric in its similarity to the concept 'race cleansing or purification' as with the Holocaust and the 'cleansing' of the Arian race in order to 'purify' it. [10] Similarly, Adorno would not agree with the following statement of Hofmann [19]:

...The barbarity of writing a poem after Auschwitz stands in strict opposition to the barbarity of not writing poetry after Auschwitz.

Adorno also cannot agree with the following statement, because of the mystical and sacred nature it dedicates to the Holocaust:

.... attempting to condense the incomprehensible suffering of the Holocaust into a few lines of poetry would violate the inner incoherence of the event, casting it into a mould too pleasing or too formal... [41, p.555]

According to Adorno [22, pp.61-131], 'the object' (Holocaust in this case, but it could also have been a piece of architecture) should never be given sacred importance, as it is in M. Heidegger`s philosophy. I. McDonald [42, p.123] tries to explain Adorno's thoughts about Celan, through identifying the meaning of the concept of "forgetting" in Adorno, Heidegger, and Celan. On the basis of this he says that according to Adorno's thoughts, Heidegger "ontologizes the ontic," and this thought is also reflected in Celan's poetry.

\section{Generality of Adorno's Dictum}

Although Adorno never stopped writing and interpreting poetry after declaring his famous dictum, he also never stopped criticizing Auschwitz poetry, such as Clean's. This unusual situation opened the way for two different interpretations about the generality / particularity of his dictum.

According to J. M. Bernstein's [43] and W. L. Moar's [44] approach, Adorno wished to produce an overall 'axial turn' in moral consciousness. This meant that culture, as whole, including all arts should be interrupted, because of their contribution to the barbaric attitude portrayed by human culture.

If culture has become barbaric, poetry (and all types of art, including architecture) should not be seen as separate from that culture. It is also responsible for contributing to barbaric situations and events. In other words, the culture which produced the lyric poets also produced concentration camps. 'There is no culture after the Holocaust: this is the barbaric as culture. '[44] According to this approach culture on any level has failed, and become an untruth. Adorno's following statement seems to support this view: [45, p.55] 
The idea that after this war life will continue 'normally' or even that culture might be 'rebuilt' -as

if the rebuilding of culture were not already its negation- is idiotic...

This means that nothing (including poetry, other arts and architecture) can continue in the same manner as it did before, following Auschwitz. There is neither a time limit, nor any other condition, which can alter this fact. This approach contains no sign of hope for the future. Thus, Adorno's dictum becomes generally applicable to all art produced after Auschwitz. This is the approach, which is shared by most of the contemporary researchers, such as Gubar [18], Hofmann [19], Caygill [20], and Kaufman [17], because they wish to refute Adorno's dictum as a whole.

On the other hand, according to C. O. Jacob [46], Adorno acknowledged the interruption, caused by the happening of Auschwitz, and he wished to participate in this interruption, which would end the barbaric way of life and being, and begin a new with fresh dialectical relationships. The world is now, (or soon will be) in new and different dialectical relationships, with renewed hope. Thus, there should be no artwork, which causes hatred and competitive relationships between people, after Auschwitz. Only the artworks, which are based on hopeful resistance, should be supported. According to this approach, Adorno's dictum should have banned only the poetry and artworks, which are based on dead dialectical relationships, but not the rest.

It is not possible to support one of these approaches, because there still remains important questions to answer in order to understand more about the possibility of hope both in Adorno's dictum and Teymur's question. What creates the beginning of new dialectical realtionships, which open the way to new conflicts between the individual artist and society? What is acceptable as a sign of hope for a society of victims?

\section{Replacing Poetry with Architecture}

With reference to Adorno`s philosophy, 'good`architects can be expected to be sensitive about the danger of disasters, such as earthquakes, as much as poets are expected to be sensitive about the context and content of social antagonisms. Here, the term 'good, refers to those individual architects, who are both critical and creative. On the other hand, a poet cannot be called a poet if his/her work is bad.

Whilst the poets' language reconciles the social antagonisms, the architects' language reconciles the antagonisms between architectural technology and nature (especially on account of the relative lack of experience in the science fields), as one of the basic antagonisms between the individual architect and society. In terms of building technology, Adorno's approach expects 'the ultimate sensitivity' of artists from the 'good' architects.

Building techniques (which determine the order), building materials, and details form the materialistic language of tectonics in architecture. Thus, 'good' architects are expected to be critically creative about both the building techniques, materials and details. No architect can change the division of labour in the building market / sector, but the 'good' architect can still continue to be critically creative about building technology and its relationship with society and nature. S/he can find ways of being creative and careful about the dialectical conflict between the building market / sector, and people / nature. 
According to Adorno's philosophy, the artistic expression of conflict (such as the dialectics between the building market / sector, and society / nature) using architectural design as a medium is not sufficient. 'Good' architects (architects as individuals or teams of architects as individuals) should also be able to provide particular rational solutions for technical problems. They should be critical of the building market / sector, inform people through the various media forms, and they should form and encourage the development of critical pressure groups within society, which would ultimately change attitudes and the building procedures themselves. These two actions requisite of individual architects are also highlighted by Adorno [35, p.40] in his "Functionalism Today." However, Adorno gives priority to social criticism rather than creativity. In this respect, Teymur's non-lyrical, poetic question demonstrates a particular approach to Adorno, which is very different from that of Heynen, as it does not limit the responsible architects' critical capabilities. In other words, by replacing poetry with architecture Teymur questions critical (and 'authentic') architecture, and the critical architect.

On the other hand, the occurence of a disaster (including the collapses, failures, deaths and losses) means that the 'good` architects were not successful in achieving any change in respect of the barbarism of the building market / sector. Each disaster is an announcement of the reification of the 'good' architects, as well as all other related 'individuals.' The warning, which should have been given by these 'good' architects and the 'authentic' architecture, has already been delivered in the form and occurence of the disaster. Adorno would say that, now, everybody is aware of the barbarism of the building market / sector in Turkey. There is no longer anything to reveal for professional architects and architecture.

According to Adorno's philosophy, it is not possible to produce 'authentic' architecture whilst already knowing that it will not be constructed using proper building techniques and materials. In such a situation the designer cannot imagine the materials properly. S/he cannot articulate the order of details, and cannot continue his/her artistic rationality. On the other hand, even if it 'was' possible to produce an 'aestheticly authentic' piece of individualistic architecture within the "mess (or garbage) of millions," such a product would be tantamount to teasing the masses. Such a piece of architecture would also serve to perform as an act of peace with the unpeaceful power, because of the spontaneous reconcilation in all art fields. Thus, according to Adorno 'aestheticly authentic' architecture, which is present in a disastrous 'world,' is barbaric. Can any 'unauthentic' architecture (such as a product of culture industry), which is under disastrous conditions, be considered as nonbarbaric? I will give the answer of this question in conclusion after examining some examples of aesthetics within totalitarian conditions.

It seems that the only way out for 'good` architects after such a disaster is to be 'silent,' but "only" in terms of 'individualistic' (authentic) artistic expression. They should continue to design. They should even try to create or find ways of achieving non-individualistic (not authentic) but still critical aesthetics. On the other hand, all individuals, and especially the 'individual' architects and structural engineers, should continue to criticize with an increasingly louder voice in all forms of the media, and strive to form effective pressure groups, which oppose the political situation, in turn, adversely affects the building market / sector. 
When Adorno`s dictum is considered, it is not easy to answer when poetry will become possible again after a genocide, such as the Holocaust. However, it is easier to imagine the answer to this question when it is applied to architecture and disasters, such as the Kocaeli earthquake. `Authentic` architecture will again become possible only when the man-made conditions, which contributed to the disaster of the Kocaeli earthquake are overcome. After the elimination of the disastrous barbarism in the building market / sector, which, in turn, reflects the barbarism of the whole political economy, new hopes can arise together with new dialectical conflicts. This also means the appearance of 'individuals' (and the 'individual' architects and structural engineers), and thus a society.

\section{SUGGESTIONS FOR ARCHITECTURE OPERATING WITHIN TOTALITARIAN CONDITIONS}

According to B.K.H.A. Speer [47], who was the architect of A. Hitler, all architectural styles existed in all types of political regimes. Thus, he thinks that no particular style belongs specifically to either democratic or totalitarian regimes. However, Speer considers only public and symbolic architecture and not the settlements of people. Looking at peoples' settlements within different political regimes (such as communism, democracy, Islamic republic etc.) might produce different conclusions. Still, any architecture, which is designed to help people to physically react against totalitarian authorities, can easily be identified and destroyed by those in power. However, building activity, as well as life and -underground- resistance, have always existed and will continue to do so under all types of totalitarian conditions.

The successful architecture of historical, totalitarian regimes is that of vernacular architecture, which has saved many lives within its narrow streets. Most of vernacular architecture served nomadic or semi-nomadic purposes prior to modernity. Both the architecture and the furniture were designed in such a way that their temporary abandonment was possible. [48] The aesthetic characteristics of all types of vernacular architecture are still appreciated within most theories of contemporary architecture. Although vernacular architecture cannot be described as contributing an aesthetic approach to architecture, the outcome is usually accepted as aesthetical. These aesthetics are achieved as a result of the rational application of commonly accepted schemas and patterns to certain situations by traditional master builders. $[49,50]$ It is by only the selection of specific materials and the quality of the commonly accepted construction details indicate the signature of a master builder. [51, 50] People were also able to maintain these buildings with the support of the solidarity, which existed between them. Thus, vernacular architecture is not an individualist approach, and its aesthetics are mostly based on its similarity with and its difference to other buildings in the vicinity. This is very similar to the aesthetics in nature, [52] e.g. the aesthetics represented by the similarity and difference between the leaves of a tree. However, according to Adorno's approach, the vernacular architecture of historical times represents the obedience and submission of individual designers (not people) to totalitarian regimes. Both vernacular architecture, and squatter architecture, which is a deformed version of vernacular architecture, still exists. These forms are known as 'architecture without architects.'

On the other hand, a careful understanding of the contemporary politics of the $21^{\text {st }}$ century shows that totalitarianism does not only belong to certain political regimes anymore. Instead all regimes can become 
totalitarian within some of their fragmented regions of sovereignty. [53] Thus, contemporary examples of architecture, which are created within such totalitarian conditions (in Adorno's terms without any social conflict), can be found within war, civil-war and disaster areas, in which the mobilization of people is very high. There are many victims, migrants and/or refugees in such areas.

It is possible to specify the actions of volunteering groups of architects / structural engineers, and architects / structural engineers, who work for NGO's within war, civil war, and disaster areas, as contemporary architectural approaches, which may represent the social responsibility of the $21^{\text {st }}$ century individual designers. P. Somma's [54] book "At War With the City", Y. Hürol Al's [55] "Van File: Compulsory Migration, Technological Disaster, Poverty - Architecture”, Y. Saifi's [56] “A Study of Power and Modern Architectural Aesthetics, The Case of the French Hill District; East Jerusalem," and Open House International's issue: "Managing Urban Disasters" [57] contain many examples of these types of architectural activities. There are also some groups of architects who design for homeless people. I. Glasser and R. Bridgman's [58] "Braving the Street" and D.J. Brown's [59] "The Home House Project" contain interesting approaches by architects to the issue of homelessness.

It must also be said that it is not possible to make an immediate ethical differentiation between the architecture of volunteer architects / structural engineers, NGO sponsored buildings, profitable products of architecture, as well as the building activities of authorities, if they all exist within the same political-economic milieu. Such ethical judgments about architecture require a detailed investigation into each case. Thus, is aesthetics the only criterion for an immediate ethical judgment in war, civil-war, disaster and homelessness areas? I will give the answer of this question in conclusion.

Consequently, it is not surprising to discover that most of the contemporary architectural examples, which may be seen as representing the social responsibility of the individual architects of the $21^{\text {st }}$ century, are bad examples of architectural aesthetics. The aesthetically successful examples of socially responsible architecture have some similar characteristics to vernacular architecture. They either develop traditional technologies and / or include people in the design and / or construction processes through participatory and time-based approaches. [60, 61] The use of traditional materials and techniques give a haptic quality of vernacular architecture to the surfaces of some of these buildings. Similarly, the use of participatory and time-based approaches, in some way, gives these buildings aesthetic qualities, which are similar to the aesthetics of vernacular architecture. Both of these aesthetics are based on the similarities and differences between various units. The materials and building techniques of some of them are selected in such a way as to enable the future users/owners of these buildings to build their own houses. Some of them offer simplified interpretations of contemporary or available building materials, construction techniques and details, and some others can only be built under professional control. The similarities between this architecture and vernacular architecture can be identified as simplicity, rationality, objectivity, flexibility for change, non-artistic approach to architecture, and possessing an aesthetic quality, which is based on the natural variety of different units. Figure 1 shows an example of the aesthetics of the participatory and time-based approach. This demonstrates a very modest aesthetic in comparison to the aesthetics, which are achieved through the conceptual and contextual approaches to architectural design. This 
aesthetic is temporary. It is not individualistic, therefore, not 'authentic.' However, it is still critical. Since any commonly accepted design idea and building techniques/details are refused by the architects of the participatory and time-based approaches, the actual products differ from the vernacular architecture. Although these approaches have many similarities to vernacular architecture, they do not represent the obedience of the 'individual' architect to power.

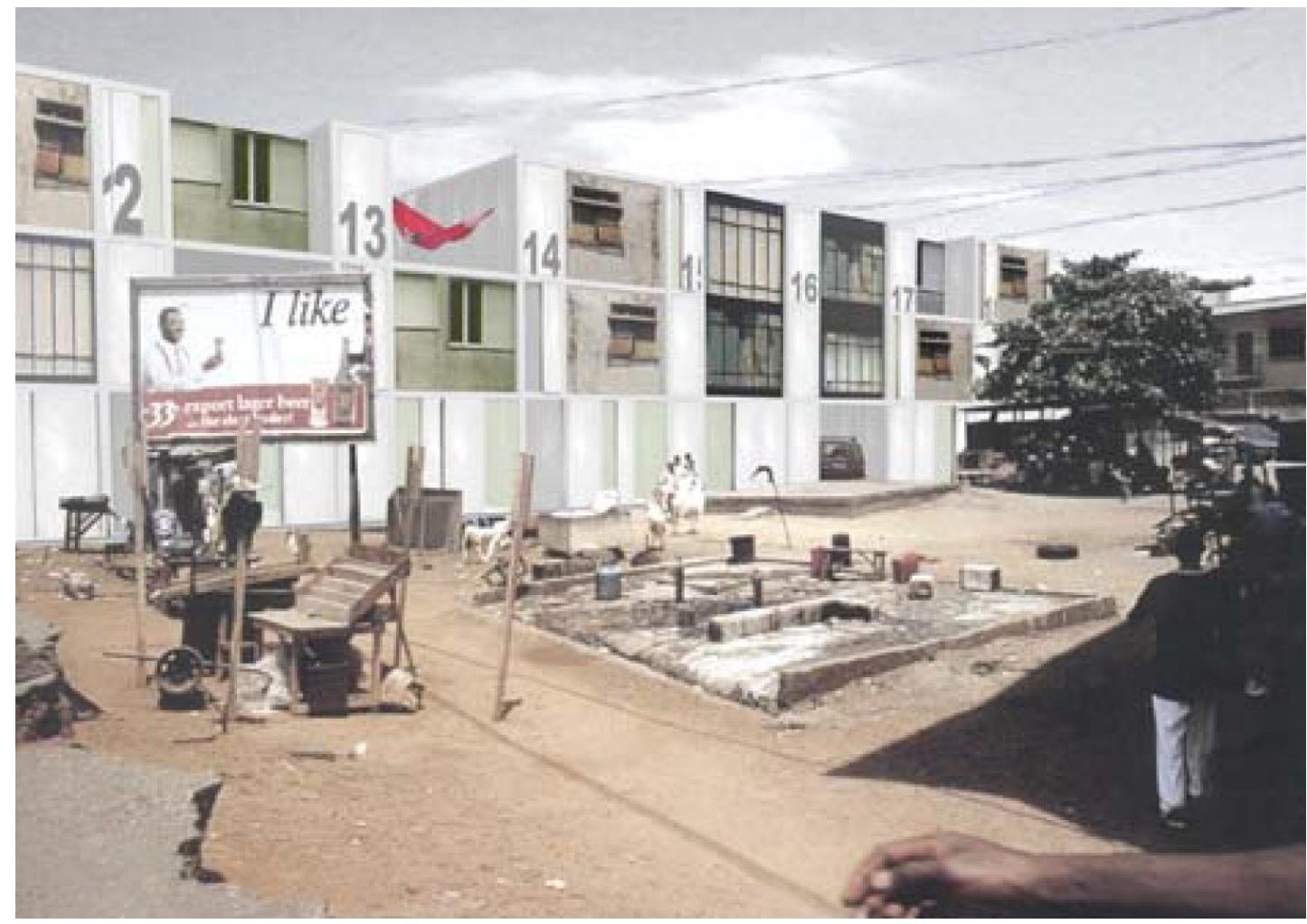

Figure 1. Title: Steps 'n Slabs,

Location: Social housing project in Temuco, Chile

Date: 2004 - 2008

Architecture: pasel.künzel architects

Rotterdam, The Netherlands (pasel.künzel architects)

By considering such contemporary architectural experiences it can be suggested to those architects, who work within totalitarian conditions, to follow a non-artistic, simple, and objective approach, and to achieve a later and indirect aesthetic outcome through the flexibility of the building and the participation of people.

\section{CONCLUSION}

There are four major interrelated issues in respect of N. Teymur's question ('Is architecture possible after 17th of August?'), which is posed with reference to T. W. Adorno's dictum ('To write poetry after Auschwitz is barbaric. ').

1. Is 'authentic'or 'aesthetical' architecture possible in Turkey, whilst the barbaric attitudes within the building market / sector remain unchallenged? Untill this challenge takes place, there can be no expression of any dialectical conflicts concerning the 'authenticity of architecture under the current conditions. This is clearly demonstrated by the extreme event of the Kocaeli earthquake, after which the conflict between individuals and society made everybody aware of the barbarism of the building market / 
sector in Turkey. Thus, any type of 'authentic' architecture is barbaric. However, according to Adorno's 'negative dialectics' the antagonistic concepts of 'authentic architecture' and 'the architecture of culture industry' do not correspond to any real architecture, which always presents a mixture of these concepts. Instead, we can only understand architecture in terms of these extreme concepts. Thus, not only authentic architecture, also all aesthetical architecture under Turkey's current conditions is barbaric. Since any aesthetical architecture more or less contains authenticity, therefore, it is possible to give an immediate decision about the ethics of that architecture, which is under totalitarian conditions, on the basis of its aesthetic characteristics. This also applies to Herzog \& de Meuron's design for the Olympic Stadium in Beijing.

2. Did the Kocaeli disaster not show that individuals and society have been reified for many years in Turkey? The answer is that yes it did, and there are two major reasons for this reification. The effect of the corrupt (even mafiatic) Turkish authorities, who do not want any change especially in the building market / sector, can be considered as the primary reason. These authorities work towards creating unity amongst people by imposing a nationalist ideology, as well as the barter principle in order to reduce the effect of all types of criticism. [1] The following quotation represents one dimension of the effect of these corrupt authorities on the building market / sector in Turkey:

.... In Turkey, building code violations were part of a well entrenched political process of give and take between the same key players - professional groups, government and industry. .... the role of central government has been crucial in sanctioning the excessive trade-offs witnessed against the value of life-safety, in pursuit of state organizational goals. Clientilism and the corruption which it nurtures institutionalizes and legitimizes those trade-offs. The advantage for the state is two fold: clientilism creates the climate which allows local corruption to flourish; corruption, in turn, ensures the provision of cheap mass housing. Corruption is thus a cheap and devolved means by which the Turkish state 'addresses' social housing provision. In this sense, it can be said to foster state organizational goals and may explain why it is tolerated. Corruption may also be seen to service another primary organizational goal - that of maintaining the integrity of the Turkish state. The political stability which clientilism brings..... and from which corruption flows may also thus be seen as an intrinsic goal. [1, p.536]

The second reason for the reification of individuals and society in Turkey is the lack of effective criticism, because the majority of the upper level bureaucrats and -the 'intellectuals,'support the corrupt authorities in whatever they do. In other words, the class of professional managers and influential people are created by the state, so that the state will be supported whatever it chose to do. These upper level bureucrats in all institutions do not permit individuals to be effective. The masses prefer to follow these powerfull bureucrats and the fake 'intellectuals,' because they are either fearful, or they also want a share of the power. 
This relationship between the masses and these bureucrats / fake 'intellectuals' is a good example of the deformation of the one-sided relationship, which exists between the person and society. It can also be described as the deformed form of Levinas's community in unity. These ideological bureucrats / 'intellectuals' have sacred 'neighbours' to love and 'enemies' with whome to fight. They religiously obey the same value system as their 'neighbours.' These 'neighbours' are the ones who support the Turkish state, and the 'enemies' are the ones who criticize it. This situation also applies to Turkish universities, including the faculties of architecture.

....With the suppression of academic debate and the dismissal of academics critical of the regime, patronage rather than merit came to determine academic appointments. [1, p.540]

A British academic in architecture, N. Wilkinson, states that a leading professor in a leading university in İstanbul had to go to a park with him: 'just like secret agents,' in order to be able to talk about the problem of low quality construction of government housing in Turkey. This eminent proffessor refused to have this conversation, the content of which was critical of the state, in front of other people.

On the other hand, some Turkish architects, who prefer not to support the state, form another type of onesided relationship with society. These people try to change society without being changed by it. They design in an artistic fethishist way, which serves for the culture industry. This is another example of the deformation of a one-sided relationship between the person and society. It is a deformed form of Arendt's approach to the relationship between the `persona` and society. The `mask` protects the `persona` from society, but s/he feels free to speak through the opening in the mask.

Following their 'elite` teachers, the new graduates of architectural faculties had to move quickly in order to adapt to the building market / sector, as well as the corrupt politics of the country. The majority of young architects see this adaptation as an important target to achieve.

On the other hand, most of the 'criticism` within this damaged society is also not objective. Both the groups in power and in opposition produce fake criticism for the sake of achieving some short term benefits. They are usually not sincere. Within this mechanism the rational actions of a few individuals in the state are also devalued. Thus, it becomes very difficult for people to become properly informed, to think, and to discuss objectively. The insincerity of such criticism serves to further increase the hatred of all authorities towards all types of criticism.

3. Since 'authentic' and 'aesthetical' architecture is not possible, it is also, therefore, not possible to produce careful and creative architectural techniques and details. This causes further problems for the earthquake issue in Turkey. There can only be instrumental rational solutions. Without the experience of being an individual it is not possible to design artistic architectural details, and techniques, which appear on the building as individuals appear within the society. Such a desire to deal with technology combines together with the experience of being an individual. Most of the architects are not even interested in the 
disasterous building technology in Turkey. They either produce some typical projects, or schematic forms of architecture. The artistic consideration of the dialectics present between technology and nature / society could only become the major target of Turkish architecture, after the total renewal and reversal of the barbaric procedures and attitudes in the Turkish building market / sector has taken place effectively.

4. Is it possible to achieve certain types of architectural aesthetics under totalitarian conditions? The generality / particularity of Teymur's question is clear. The more or less 'authentic,' in other words 'aesthetical' architecture is 'impossible,' until the disastrous characteristics of the building market / sector are eliminated. Although it is not easy to say that Turkey has a totalitarian regime, it is clear that the dialectical conflict between society and the individual has seriously deteriorated. On the other hand, it is possible to suggest that Turkish architects and structural engineers (the ones who contribute to aesthetics of architecture), who work under totalitarian conditions, follow a non-artistic, objective, and participatory / time-based approach, which does not exclude a modest and late-coming aesthetics due to people's participation, until those disastrous characteristics of the building market are eliminated.

In the light of Teymur's question, the generality / particularity of Adorno's dictum can also be clarified. The following hierarchical conditions for the production of 'authentic' poetry are parallel to the corresponding conditions for the production of 'authentic' architecture:

1. The existence of 'individuals,' who are critical, and a 'society,' which is open to radical but rational changes, in order to achieve worldwide peace.

2. The existence of a dialectical conflict between the artist and society, which will let the formation of 'assemblages' or 'fragments` through the autonomy of the technological details within poetry.

If there is no such society, there cannot be 'authentic' poetry, as well as 'authentic' architecture, which more or less includes all aesthetical architecture. If there is no dialectical conflict between art and society, then, 'authentic' poetry, or aesthetical architecture cannot exist. The 'authentic' arts, including the aesthetics of architecture, cannot co-exist with (internal and / or external) totalitarian politics. There is a direct relationship between the political economic regimentation and the possibility of producing 'authentic' art, which includes 'authentic' and 'aesthetical' architecture, and technological creativity.

This outcome differs from the thoughts of Caygill [20], Gubar [18], Hofmann [19] and Kaufman [17], because they think that Adorno's dictum will always be equally strong and valid following the catastrophy of Auschwitz. It also differs from Zilcosky's [21, p.672] interpretation: 'Adorno is not forbidding poetic speech, rather he is reacting to a certain kind of poetic speech - saccharine postwar poety - that attempts to repress and/or retouch the Holocaust. ' However, according to the results of this research, it is not the content of the poetry, but the very existence of internal / external totalitarian conditions, which renders Adorno's dictum valid.

On the other hand, the 'romanticism' of making any 'authentic' architectural expression of the dead conflict between "the building market / sector" and "society / nature" in Turkey, following the 17th of August 1999, is barbaric, because it makes peace with the unpeaceful and corrupt political authorities. 
A man undergoes pain sitting at a piano

knowing thousands will die while he is playing

He has two thoughts about this

If he should stop they would be free of pain

If he could get the notes right he would be free of pain

In the second case the first thought would be erased

causing pain

It is this instance of playing

he would say to himself

my eyes have grown hollow like yours

my head is enlarged

though empty of thought

Such thoughts destroy music

and this at least is good.

[62, p.19 in 63, p.108]

\section{References}

1. Green, P., (2005) Disaster by Design- Corruption, Construction and Catastrophe. British Journal of Criminology. 45. pp.528-546.

2. Güvenç, K., (2002) 17 Ağustos'un Üçüncü Yılında.

http://tmmob.org.tr/modules.php?op=modload \&name=News\&file=article \&sid=272\&mode=thread (Accessed date: 11 August 2006)

3. Teymur, N., (Ed.) (1999) Learning from Disasters. Ankara: METU Faculty of Architecture Press.

4. Teymur, N., Teymur, E., (1978) Mimarlıktaki Tartışmaların Statüsü. In M. Pultar (Ed.) Mimarlık Bilimi Kavram ve Sorunları. Ankara: Çevre ve Mimarlık Bilimleri Derneği. pp.1-8.

5. Hürol (Al), Y., (2004) Değişim ve Mimarlar Odası. Ankara: Mimarlar Odası Yayınları. pp.15-21.

6. Teymur, N., (2002) Re:Architecture- Themes and Variations. London: ?estion Press.

7. Teymur, N., (2005) DEPREM(DE) Şİ̈R. İstanbul: Yap1 Yayın.

8. Wilcock, E., (2003) To write a poem after Auscwitz is barbaric.

http://www.marcuse.org/herbert/people/adorno/AdornoPoetryAuschwitzQuote.htm

(Accessed date: 14 September 2006)

9. Adorno, T. W., (1995) Prisms. Trans: Samuel and Shierry Weber. $8^{\text {th }}$ Print. Cambridge Massachusetts: The MIT Press.

10. Croggon, A., (2005) MIAF Knob-Jockey Awards. Critic Watch.

http://criticwatch.blogspot.com (Accessed date: 11 August 2006)

11. Celan, P., (1972) From Poems of Paul Celan. Trans: M. Hamburger. Persea Books. 
12. Peaker, G., (1998) Adorno...Beauty's Wounds.

http://www.thing.net/eyebeam/msg00424.html (Accessed date: 12 August 2006)

13. Duffy, C., et. al., (1998) Adorno...Beauty's Wounds.

http://www.thing.net/eyebeam/msg00424.html (Accessed date: 11 August 2006)

14. Adorno, T. W. (1998) Aesthetic Theory. Trans: R. Hullot-Kentor. $2^{\text {nd }}$ Print. Minneapolis: University of Minnesota Press.

15. Jay, M., (1984) Adorno. Cambridge. Massachusets: Harward University Press.

16. Cunningham, D., Mapp, N., (Eds.) (2006) Introduction. In Adorno and Literature. NY: Continuum International Publishing Group. pp.1-5.

17. Kaufman, R., (2006.b) Poetry's Ethics? Theodor W. Adorno and Robert Duncan on Aesthetic Illusion and Sociopolitical Delusion. New German Critique. 97. Vol.33. No:1. Winter.

18. Gubar, S., (2003) Poetry after Auschwitz: Remembering What One Never Knew. Bloomington: Indiana University Press.

19. Hofmann, K., (2005) Poetry after Auschwitz - Adorno's Dictum. German Life and Letters. 58: 2 April. pp.182-194.

20. Caygill, H., (2006) Lyric Poetry before Auschwitz. In Adorno and Literature. Cunningham, D., Mapp, N., (Eds.) NY: Continuum International Publishing Group. pp.69-83.

21. Zilcosky, J., (2005) Poetry After Auschwitz? Celan and Adorno Revisited. Deutsche Vierteljahrsschrift fur Literaturwissenschaft und Geistesgeschichte. 79 (4). December. pp. 670-691.

22. Adorno, T. W., (1994) Negative Dialectics. Trans: E. B. Ashton. $2^{\text {nd }}$ Print. NY: The Continuum Publishing Company.

23. Adorno, T. W., (1993) Subject and Object. In A. Arato, E. Gebhardt. The Essential Frankfurt School Reader. NY: Continuum. pp.497-511.

24. Adorno, T. W., Horkheimer, M., (1995). Dialectics of Enlightement. Trans: J. Cumming. $4^{\text {th }}$ Print. London: Verso.

25. Adorno, T. W., (1996.a). Culture Industry. $4^{\text {th }}$ Print. London: Routledge.

26. Adorno, T. W., (1991) On Lyric Poetry and Society. Notes to Literature. Vol.1. Trans: S. W. Nicholsen. NY: Columbia University Press. pp.37-54.

27. Adorno, T. W., (2000) Introduction to Sociology. Trans: E. Jephcott. $2^{\text {nd }}$ Print. California: Stanford University Press.

28. Arendt, H., (1970) On Violence. NY: Harcourt.

29. Arendt, H., (1958) The Human Condition. Chicago: University of Chicago Press.

30. Arendt, H., (2003) Responsibility and Judgement. NY: Schocken Books.

31. Levinas, E., (1994) Totality and Infinity: An Essay on Exteriority. Trans: A. Lingis. Pittsburgh: Duquesne University Press.

32. Levinas, E., (1993) Outside the Subject. Trans: M. B. Smith. London: The Athlone Press Ltd.

33. Levinas, E., (1981) Otherwise than Being or Beyond Essence. Trans: A. Lingis. Boston: Martinus Nijhoff Publishers. 
34. Griffiths, A. P., (Ed.) (1993) Ethics. Cambridge: Cambridge University Press.

35. Adorno, T. W., (1979) Functionalism Today. Oppositions. 17. pp.31-41.

36. Leatherbarrow, D., Mostafavi, M., (2005) Surface Architecture. Cambridge. Massachusets:

The MIT Press.

37. Deleuze, G., Guattari, F., (1993) A Thousand Plataeus; Capitalism and Schizophrenia. $4^{\text {th }}$ Print. Minneapolis: University of Minnesota Press.

38. Heynen, H. (1992) Architecture Between Modernity and Dwelling; Reflections on Adorno's Aesthetic Theory. Assemblage: A Critical Journal of Architecture and Design Culture. 17. pp.79-91.

39. Dixon, M. J. C., (n.d.) Adorno on Technology and the Work of Art. http://www.ariada.uea.ac.uk/ariadatexts/ariada1/content/Technik.pdf (Accessed date: 11 August 2006)

40. Adorno, T. W., (n.d.) Lecture Fourteen. Metaphysics. 110; Metaphysik. pp.172-73.

41. Langer, L., (1995) Art from the Ashes: A Holocaust Anthology. NY: Oxford University Press.

42. McDonald, I., (2006) Returning to the 'House of Oblivion': Celan between Adorno and Heidegger. In Adorno and Literature. Cunningham, D., Mapp, N., (Eds.) NY: Continuum International Publishing Group. pp.99-116.

43. Bernstein, J. M., (2001) Adorno: Disenchantment and Ethics. Cambridge: Cambridge University Press.

44. Moar, W. L., (n.d.) Adorno: Semi-Formation as Cultural Reconstruction of Society. http://www.bu.edu/wcp/Papers/Soci/SociMaar.htm (Accessed date: 11 August 2006)

45. Adorno, T. W., (1996.b) Minima Moralia. Trans: E. F. N. Jephcott. ${ }^{\text {th }}$ Print. London: Verso.

46. Jacob, C. O., (2003) Interrupting Auschwitz.

http://www.janushead.org/7-1/InterruptingAuschwitz.pdf (Accessed date: 11 August 2006)

47. Speer, A., (1995) Architektur Arbeiten 1933 - 1942. Propylaen.

48. Çamuroğlu, R., (1999) Tarih Heterodoksi ve Babailer. 3.baskı. İstanbul: Om Yayınevi.

49. Lewcock, R. (2006) Generative Concepts in Vernacular Architecture. In Vernacular Architecture in Twentyfirst Century. L. Asquith, M. Vellinga, (Eds.) NY: Taylor \& Francis.

50. Aran, K., (2000) Beyond Shelter: Anatolian Indigenous Buildings. Ankara: Tepe Architectural Culture Center.

51. Hubka, T., (1986) Just Folks Designing: Vernacular Designers and the Generation of Form. In Common Places- Readings in American Vernacular Architecture. D. Upton, J.M. Vlash, (eds.) Athens. Georgia: The University of Georgia Press.

52. Alexander, C., (1979) The Timeless Way of Building. New York: Oxford University Press.

53. Balibar, E., Wallerstein, I. (Eds.) (1992) Race Naiıon Class, Ambiguous Identities. London: Verso.

54. Somma, P., (Ed.) (2004) At War With the City. Great Britain: The Urban International Press.

55. Hürol Al, Y., (Ed.) (1998) Van File: Technological Disaster, Compulsory Migration, Poverty - Architecture. Ankara: UCEAT Chamber of Architects. 
56. Saifi, Y., (2006) Unpublished Masters Thesis: A Study of Power and Modern Architectural Aesthetics: The Case of the French Hill District; East Jerusalem. Eastern Mediterranean University EMU.

57. Wamsler, C., (Ed.) (2006) Managing Urban Disasters. Open House International. Vol: 31. No:1.

58. Glasser, I., Bridgman, R., (1999) Braving the Street - The Anthropology of Homelessness. NY: Berghalm Books.

59. Brown, D.J., (Ed.) (2004) The Home House Project - The Future of Affordable Housing. Cambridge Massachusetts: The MIT Press.

60. Habraken, J., (1998) The Structure of the Ordinary - Form and Control in the Built Environment. J. Teicher, (Ed.) Cambridge Massachusets: The MIT Press.

61. Leupen, B., Heijne, R., Zwol, J., (Eds.) (2005) Time-based Architecture. Rotterdam: 010 Publishers.

62. Palmer, M., (1988). Sun. San Francisco. CA. North Point Press.

63. Kaufman, R., (2006.a) Lyric's Expression: Musicality, Conceptuality, Critical Agency. In Adorno and Literature. Cunningham, D., Mapp, N., (Eds.) NY: Continuum International Publishing Group. pp.99-116. 